$\Phi=1$ -

\title{
Unani methods of cure in the Indian subcontinent : an analytical study
}

\author{
Arshad Islam \\ *Corresponding author E-mail: arshadislam2@gmail.com
}

\begin{abstract}
The history of medicine is bound with the history of civilization, representing the complex interactions of human communities, geography and the environment over time. South Asia has always been a vibrant melting pot of interactions between different peoples. Unani ('Greek') medicine is based on ancient Hellenic thought (via its interactions with Babylonian, Egyptian, Indian and Persian knowledge). Tibb-i-Unani is Arabic for 'Greek medicine', which became Unani as practiced in the Indian Subcontinent, where it was developed and refined through systematic experimentation by renowned scholars. Islamic physicians tested Indian traditional medicines using clinical trials, as a result of which they incorporated a number of indigenous medicines in their own system, advancing and enriching its treasures. The basic Unani framework is timeless, based on human action and intrinsic causes. This paper highlights the subtler and perhaps more important aspects of classical Indian Unani medicine that contributed to the development of the entire body of scientific knowledge. Through an analysis of socio-cultural and historical context, the paper concludes that the contribution of Unani medicine in India lies in: (a) preserving the ancient Greek tradition of medicine; and (b) safeguarding and advancing utilitarian medical science and treatment into the early modern period.
\end{abstract}

Keywords: Ayurvedic medicine; Greek medicine; Unani medicine

\section{Introduction}

The history of medicine is a complicated field, as medicine itself is difficult to define and to trace in the ancient world. It is clear that medicine has always been permeated with the worldview of its practitioners, thus its most ancient manifestations are bound up with supernatural concepts as well as more prosaic processes of trial and error with the use of incantations, herbs, compound preparations, ablutions, exercises and incense to treat maladies considered as much spiritual as biological. As long as there has been illness there has been medicine, and both have been understood in a cultural framework sensitive to the spiritual and metaphysical doctrines of the human communities in which they occur.

While the manifestation of medicine assumes cultural attributes, as a discipline it has exhibited remarkable continuity between contemporaneous and successive civilizations over time, particularly from ancient Egypt to Greece and then to the Roman Empire. As the latter disintegrated in Europe, studies of classical Greek medicine declined in the West, while witnessing a remarkable awakening throughout the Islamic world, disseminated mainly by Arab and Persian physicians who drew on the legacy of the Byzantines as well as the indigenous Greek traditions preserved in Central Asia and India from Bactrian civilization. In West Asia and North Africa the lingua franca of knowledge during the classical Arab-Islamic period (c. 800-1400 CE) was Arabic, which was an essential requirement for Persian, Indian, Chinese and European scholars seeking knowledge in medicine and other sciences considered an integral part of Islamic knowledge in Muslim civilization. Muslim scholars translated all available medical literature into Arabic, including volumes procured specially from the imperial libraries of Constantinople as well as ancient Sanskrit lore from India, with extensive revision and commentary based on deduction and experimentation,(1). This synergy of world traditions was enabled by both peaceful interactions with other civilizations and by early Arab conquests, such as of Egypt and Persia, which united venerable centres of learning in Alexandria and Jundishapur (modern Shahabad, Iran) in a single state for the first time since Alexander the Great (d. 323 BCE)(2).

\section{Literature Review}

While there is a significant body of literature on the subject such as Atibba-e-Ahde Mughliya by Hakim Ali Kausar Chandpuri, Aina-e-Tarikh Tibb by S. Zillur Rahman, and Hindustan mein Tibb-i-Unani ka Aghaz wa Irtiqa by Altaf A. Azmi, they concentrated mainly on the initiation of Tibb-i-Unani in the Indian Subcontinent under the Muslims. The present study does not seek to recount its historical development, but to highlight the more subtle aspects of Indian contributions to classical Unani medicine that were perhaps more instrumental in the development of scientific knowledge.

\subsection{Growth in India}

While the Abbasids are more commonly associated with the Islamic Golden Age of their metropolis in Baghdad, the Abbasid educational movement spread far and wide to the regions of Asia, Africa and the Iberian Peninsula. Greeks, Alexandrians and Arabs played a major role in the evolution and growth of Tibb-i-Unani during its early stage, after which it was upheld by Persians like Abu al-Hasan Ali ibn Sahl Rabban al-Tabari (c. 810-861), Abu Bakr Muhammad ibn Zakriya ar-Razi (841-924), Ali Ibn Abbas al-Majusi (d. 996), Abu Sahl Masihi (d. 1010) and Ibn Sina (d. 1037), all of whom were Persian courtiers of the Abbasids. With 
the decline of Abbasid authority, the rising local dynasties of Central Asia undertook the patronage of the arts and sciences,(3). Notwithstanding the fact that Persian cultural supremacy remained supreme, the dynasties of Central Asia increasingly looked east to India as the locus of their economic and political civilizations, as West Asia descended into civil wars and occupations, including the Crusades and the Mongol invasions. Khusrau Malik (r. 11601186), the last Ghaznavid ruler, made his capital at Lahore where Hakim Ziya al-Din Abdur Rafe' Harvi joined as his court physician. He was the first known expert Tabib (physician) in India because of his matchless skill and excellence in his profession, $(4,5)$.

\subsection{In the Delhi Sultanate}

\section{The Ghurids}

The shift of power from the Ghaznavids to the Ghurids had a great impact on Indian soil, but we do not have specific information about the progress of Tibb-i-Unani in India until the $13^{\text {th }}$ century, when a large influx of Central Asian émigrés arrived in the Subcontinent, fleeing the Mongol onslaught from 1219 onwards (Azmi 1992). The earliest reported migration of a well know Unani hakim on Indian soil who brought the medical system as practiced in Central Asia was Hakim Ziya al-Din Abdur Rafe' Harvi, who lived until the time of Sultan Shihab al-Din Muhammad Ghuri (d. 1206).

During the rule of the Delhi Sultans, the Khaljis, Tughlaqs, Lodis and the Mughal emperors gave state patronage to Tibb-i-Unani and physicians and the discipline flourished under the care of Muslim rulers and spread throughout South Asia and the maritime civilization of the Indian Ocean. Muslim rulers devoted their energy and were personally interested in the development of Tibb-iUnani in India, as well as viewing it as an essential princely responsibility to promote the people's welfare and healthcare, thus they built hospitals and appointed specialist physicians, as well as subsidising free medicine.

\section{Shams al-Din Iltutmish}

After Muhammad Ghuri's death, his slave Qutb al-Din Aibak became Sultan of India, laying the foundation of Delhi Sultanate. He ruled extensive territories in India until his death in 1210. After his death, his slave Shams al-Din Iltutmish (r. 1210-1236) ascended the throne of Delhi, during which Albiruni's Kitab as Saydanah, a treatise on the use of drugs in medicine, was translated in Persian by Abu Bakr ibn Ali ibn Uthman Asfar al-Kashni (d. 1229), representing the earliest translation of a pharmacologic book in India (Minhaj 1954; Awfi 1982; Jaggi 1981). The period following Iltutmish's death saw intense rivalry among the Turkish nobles who mercilessly killed Iltutmish's successors. This chaotic state of affairs ended with the accession of Sultan Ghiyasuddin Balban (r. 1266-1287) (Aziz 1972).

\section{Sultan Ghiyasuddin Balban}

Hakim Najmuddin Mahmud ibn Ilyas Shirazi was one of the renowned physicians during the reign of Sultan Ghiyasuddin Balban, to whom he dedicated the eponymous Persian treatise Ghiyas al$T i b b$. It is a short and comprehensive treatise on Tibb-i-Unani, two manuscripts of which available in the libraries of Ajmal Khan Tibbiya College, (Aligarh) and Khuda Bakhsh Library (Patna), India (Azmi 2014). Another important medical work, Tibb-i-Firoz Shahi, was compiled in $680 / 1281$ by an unknown author during Balban's reign, but the title gives a confusing indication of the name of Sultan Firoz Shah (r. 1351-1388). Tibb-i-Firoz Shahi is an excellent medical tome in the field of veterinary science, particularly dealing with the treatment of birds. It is important to note that author gave both the common and local Indian names of medicines known by the people, like Ilaichi (cardamom), Methi (fenugreek), Phitkari (alum), Bhangra (elicpta alba), Sarphooka (purple tephrosia), Pilpil draz/Filfil draz (long pepper), Suhaga (borax), ghoongchi (jequirity), Lawang (clove), bayr bahuti (valvety-tick), Kafoor Bhimseni (borneo camphor), and Mehndi (henna) etc., indicating its intended use as a widespread compendium of medical knowledge for the masses; this represents a departure from the traditional sacerdotal monopoly of healing by the Brahmin caste in India (and the 'consult your doctor' mantra of commercialised modern medicine), and in modern parlance a much higher degree of patient autonomy was promoted in the Muslim sultanates due to the democratisation of knowledge in Islamic civilization. The names of these herbal medicines are still widely used in the Unani system (Rahman 2001)

\section{The Khaljis}

Under the Khaljis (1290-1320) Delhi emerged as a centre of Islamic learning and healthcare with a number of prominent physicians, including Badr al-Din Dimashqi, Hakim Sadr al-Din Marikeli and his son Hisam al-Din Marikeli, Hakim Matraz, Hakim Alim al-Din, Hakim Yamani, Hakim I'za al-Din Badauni, Ma Chandar Tabib, Jaja Jarrah (the noted surgeon) and Alim al-Din Kahal, all of whom were outstanding scholars and who promulgated clinical knowledge throughout India (Azmi 1992; Barani 2005; Tazimuddin 1980). Badr al-Din Dimashqi was an outstanding physician whose lectures on Tibb were attended by all of the physicians of Delhi. Due to his medical expertise he could guess the health of a patient and whether he could be cured by quick evaluations. He was so expert in the renal (urinary) system that he could instantly distinguish whether a sample was human, animal or a combination of both. Hakim Sadr al-Din Marikeli and his son Hisam al-Din Marikeli, both father and son, were famous for giving discourses and were proficient in aetiology (Barani 2005; Farishta 1884). Hakim Matraz, Hakim Alim al-Din and Hakim Yamani were all renowned physicians in their respective fields giving lectures on medicine. During this period there was a notable development of veterinary science as an adjunct to conventional medicine, which is of more than passing importance given the centrality of animals to early modern economies and states (Al-Hasani 1999; Agha 1996; Azmi 1992).

\section{The Tughluqs}

The Tughluqs established hospitals in Delhi and adjacent areas and promoted Unani medicine in India. Ghiyasuddin Tughluq (r. 1320-1325), the founder of the dynasty, displayed great interest in medicine and personally bandaged the wounds of injured soldiers of Khusrau Khan (d. 1320) during the conquest of Delhi in 1320 (Khusrau 1933; Wasty 1974; Azmi 1992). During the reign of Sultan Muhammad Tughluq (r. 1325-1351) there were seventy hospitals served by 1200 physicians alone in Delhi. Sultan Muhammad Tughluq, being a highly qualified physician, was chiefly distinguished for establishing and maintaining a number of excellent hospitals in and around Delhi. He took a keen interest in patients' wellbeing and treatment and a large number of his subjects benefitted from his medical practice. Many medical experts used to exchange their views and discuss intricate medical matters in his court (Barani 2005).

Ziya Muhammad Masud Rashid Zangi was the personal physician of Sultan Muhammad Tughluq and an outstanding Hakim who left a medical compendium entitled Majmua' Ziyai / Collection by Ziya (737/1336), composed during his stay in South India at Devagiri (Daulatabad), the second capital of Muhammad Tughluq. Apart from Ziya's proficiency in Unani medicine he consulted many pertinent Arabic, Persian and Ayurvedic works in Sanskrit to produce his own treatise, in which he explained the Indian names of medicines. He delved deeply into pharmacology, explaining the preparation of kushta (a calcined product) for solid dosages, surgery and astrology and the treatment of horses (which were essential to economic and military life). He left a fascinating discussion on women's nature and temperament relative to various geographical and climate regions. The author for the first time extensively discussed Indian herbs at large and assessed the temperament of Ayurvedic medicines according to the Unani pattern. 
Majmиа' Ziyai is a good amalgamation of Unani and Ayurvedic type of treatment. Ziya Muhammad Masud Rashid Zangi died in 1351(Azmi 2014).

Majmua' Shamsi by Khwaja Shams al-Din Mustawfi was written either during the reign of Ghiyasuddin Tughluq or in the beginning of Sultan Muhammad Tughluq's rule, but the original manuscript is lost and is known only from a discussion by the author of Majmua' Ziyai (737/1336) in his preface. The book is based on Sanskrit sources. Majmua' Shamsi (Collection by Shams) was one of the sources consulted by Hakim Amanullah (d. 1016/1607) in his book Ganj bad Awurd.

Sultan Firoz Shah (r. 1351-1388) upgraded seventy existing hospitals and added five more, all equipped with reputed highly skilled physicians. Apart from these hospitals, Firoz Shah built the flagship medical complex Dar al-Shifa in Delhi, which served free food and medicine to everyone, without any hierarchical or ethnic distinctions, with specialist physicians to examine patients. The annual expenditure of hospital and health care was 3,600,000 tanka, paid from the royal awqaf (endowments), which was one instance of a massive public welfare campaign in which, in addition to hospitals, Sultan Firoz Shah built numerous mosques, treasuries, schools, dams, baths, wells, bridges and gardens (Afif 1891; Barani 2005; Farishta 1885; Agha 1996; Azmi 1992; Nagrami 2000; Verma 1970).

According to Sirat-i-Firozshahi, Firoz Shah's passionate interest in hunting expeditions extended to his interest in advanced ornithological knowledge of hunting birds like hawks and falcons, about whose habitat on land, tree and mountain he had extensive knowledge (e.g. he could assay the height of birds' nests according to the terrain and locate them in short or tall trees). He recorded much of his profound knowledge in Shikarnamah Firozshahi, a compendium of ornithology and techniques for catching birds. He also recorded the shape and size of birds in terms of the head, eyes, beak, ears, throat, stomach, talons and legs. He also wrote extensively on their diseases and treatments, along with different varieties of hunting dogs and the suitable timing for hunting seasons relative to biology (Rahman 2001).

Under Firoz Shah some important medical works like Risalah Firoz Shahi of Shah Quli were compiled. Firoz Shah was an expert in religious sciences, medicine and astrology and his personal library had a handsome collection of books on these subjects. His keen interest in medicine can be gauged by the fact that the specifies the treatment of many diseases not discussed in comparable works such as Al-Qanun (Canon) of Ibn Sina and Dhakhirah Khwarazmshahi (Thesaurus of Khwarazm Shah) of Ismail Jurjani. The Sultan was an expert in orthopaedics and he set fractured bones on various campaigns. He was also an expert in ophthalmology and made kohl (surma) known as Kohl Firozshahi, a collyrium giving quick relief to eyes. Another book on medicine in Persian entitled Rahat al-Insan (Repose for Human Beings) of Hakim Ilyas ibn Shihab, known as Ziya (1377), was dedicated to Sultan Firoz Shah. In this book Hakim Ilyas gave the common Indian names of every disease and prescribed both medical as well as spiritual treatments. The book sheds light on medical and spiritual awareness and the nature of people's interactions with medicine at that time (Askari 1957; Azmi 1992).

\section{The Lodis}

The Lodi Sultans (1451-1526) played a very significant role in the promotion of Tibb-i-Unani in India. Sultan Sikandar Lodi (r. 1489-1517) was an educated and farsighted ruler whose minister Bahua ibn Khwas Khan (d. 1519) compiled in Persian a medical encyclopaedia with the help of Ayurvedic books entitled Ma'dan al-Shifa Sikandar Shahi or Tibb-i-Sikandari (Sikandar Shah's Mine of Medicine), one of the principal Ayurvedic tomes composed in India. Mian Bhu'a, after gaining mastery over Sanskrit, studied the Ayurvedic system of medicine which he combined with Tibb-i-Unani to produce his classic Ma'adan al-Shifa-i Sikandar Shahi, in 1512, based on different Sanskrit classics like Charaka samhita by Charaka, Susruta-samhita by Susruta, Jatu- karna, Bhoja, Bheda, Vagbhatta, Ras Ratna, Sarangdhara, Nabgasena, Chintamani, Madhavanidana, Chakradatta by Chakrapani Datta and Gayadatta as his source material (Bhu'a Mian 1877; Abdullah 1954; Mushtaqi 2002; Siddiqi 1959; Hadi 1995). His minister Amir Mian Taha was subsequently expert in Ayurvedic medicine and music. He memorised 24,000 Ayurvedic hymns due to his expertise, and Hindu scholars used to attend his lectures (Siddiqi 1967; Azmi 1992). Aina-e-Sikandari was compiled during the reign of Sultan Sikandar Lodi, but the author's name is missing and only a single copy is available in the library of Ajmal Khan Tibbiya College, (Aligarh). Tibb-i-Ibrahim Shahi by Khwajgi Islahullah, written during the time of Sultan Ibrahim Lodi (r. 1517-26), runs to 575 pages.

\subsection{The Mughals}

\section{Background}

With the decline of the classical Eastern Islamic civilization (from the $13^{\text {th }}$ century onwards in Central Asia), the Indian Subcontinent became the final home of the legacy of Tibb-i-Unani (Azmi 1992). Under the Safavids (1502-1722), a large number of Unani physicians made their enduring abode in Persia, where they generally found generous patronage, but political instability caused many to migrate to India in search of a better life. Soon after their settlement in India, Muslim aristocrats and intellectuals started to learn local languages, discovering Indian arts and sciences. Among the numerous branches of Indian knowledge and learning, Muslim scholars were particularly fascinated by the Indian system of medicine. They produced great works on Indian sciences in Persian and integrated the Indian Ayurvedic system of medicine into Unani, which are quite different in content from earlier works produced in Persia.

It is significant to note that the advancement of Tibb-i-Unani under the Mughals was mostly due to hard labour of Central Asian and Persian physicians who migrated towards India because of political upheavals in Persia under the Safavids and between local potentates (Akbarnamah, 1882), but a major pull factor in this migration was the support and honour received by such immigrant scholars in the kingdoms of Deccan and subsequently in the Mughal court. Additionally, due to the renown of skilled Indian physicians, Persian students began flocking to India to enrol for specialised training in Tibb-i-Unani (Rahman 2001).

\section{Early works associated with Mughal civilization}

Some early works connected to the Mughals, written in the NorthWestern Frontier and other parts of India, emerged prior to the actual establishment of the dynasty in India in 1526. Some of the earliest of these were general in nature, although they already exhibit a cohesive methodology of medical science. Fawaid alAkhyar (913/1507) comprises 48 pages on the maintenance of general health. One manuscript is available in Osmania University library (Hyderabad). Asal al-Usul ('Origins of Principles') was compiled at the beginning of $16^{\text {th }}$ century and a section of a Tibbi book carries a 36-page discourse delineating the limits and guidelines for a tabib. A copy of this risala is in Maulana Azad Library (Aligarh), copied in 1839. Risalah Makul wa Mashrub (906/1500) is a small booklet regarding Makulat and Mashrubat ('foods' and 'drinks', i.e. dietary medicine). The manuscripts are in the libraries of Raza Library (Rampur), Salar Jang Museum (Hyderabad) and Maulana Azad Library (Aligarh).

In North-Western Afghanistan, Herat was a major centre of medicine prior to the rise of the Mughals in India and it continued to be so. Ilaj al-Amraz was compiled in the city in the beginning of the $16^{\text {th }}$ century, dealing with treatment and cure in 289 rubaiyat (odes). A few manuscripts are available in the libraries of the British Museum, Asiatic Society of Bengal (Calcutta), Khuda Bakhsh Library (Patna), Salar Jang Museum (Hyderabad) and Maulana Azad Library (Aligarh). A commentary on Ilaj al-Amraz entitled Jama' al-Fawaid (913/1507) elaborates on treatment and cure in 
prose and poem. It discusses the symptoms of disease in all human body organs and their treatments, explaining sicknesses and their symptoms in prose and elaborated its treatment in poems. It further elucidates the symptoms and causes of particular diseases and explains the appropriate methods of cure in detail. A few manuscripts are available in the libraries of the Bodleian (Oxford), Asiatic Society of Bengal (Calcutta), Nizamiya Tibbiya College Library (Hyderabad), Salar Jang Museum (Hyderabad), Raza Library (Rampur), Maulana Azad Library (Aligarh) and Central library Jamia Hamdard (New Delhi).

\subsection{Babur (r. 1526-1530)}

Babur (r. 1526-30) founded the Mughal dynasty after defeating Sultan Ibrahim Lodi in the battle of Panipat in 1526. Babur was a man of letters and was an expert in Turkish and Persian, authoring works in both languages, such as his autobiography Tuzuk-i-Babri in the former, and a Persian diwan (collection of poetry), in addition to his lavish patronage of poets (Dale, 2004). Babur also showed enormous interest in Tibb and excelled in acquaintance of Unani medicines and its applications. For example, when poisoned by one of Ibrahim Lodi's chefs, Babur oversaw the preparation of medicated milk as an antidote (Babur 2007). Some of the most prominent physicians attached to his court are described below. Hakim Muhammad ibn Yusuf Harvi and his son Hakim Yusuf ibn Muhammad al-Harvi called Yusufi, both physicians in the court of Babur and Humayun (r. 1530-40), came to India accompanying Babur in 1526, and became his personal physician (Akbarnamah vol. 1, 1882, 119). He wrote in Arabic a Tibbi dictionary Bahr ul-Jawahir or Jawahir-ul-Lughat, 'Sea of Jewels' or 'Jewel Dictionaries' (c. 1532) dedicated to Sultan Jalaluddin Malik Dinar. It is written both partly in Arabic and partly in Persian, a scientific dictionary in which he recorded the method and style of treatment as well as clarification of the technical, medical and botanical terminologies. It also gives short biographies of prominent physicians. A number of manuscripts of this work are available in European libraries and also published in Tehran (Elgood, 1979).

Ainul Hayat discusses Unani medicines, diet and syrup for treating age-related issues, and the main sources of body heat. The three manuscripts are available in the Oriental Manuscripts Library and Research Institute of (Hyderabad), Raza Library (Rampur) and Khuda Bakhsh Library (Patna) (Azmi 2014).

Hakim Yusuf ibn Muhammad al-Harvi (Yusufi): apart from being an excellent Tabib, Hakim Yusufi was a literary figure and left three diwan (collections of ghazals). His literary writings are Lataif al-Nasaikh (926/1519), Qasaid Yusufi, written in the praise of Babur and Humayun and Insha-Yusufi (940/1533). The manuscripts are in the libraries of the Asiatic Society of Bengal (Calcutta), the State Manuscript Library (Madras), the India Office Library, the Bodleian (Oxford) and the British Museum. Some of Hakim Yusufi's books on Tibb are described below:

Jami-ul-Fawaid (Collection of Benefits, 1511) was written 1511 in Herat. It was translated into English entitled Annals of Medical History by Dr Lichtwardt, of the American Mission to Persia.

Qasidah dar Hifz Sehat (937/1530) deals with keeping health in daily life, hygiene and its rules. This risala was written in India during Babur's sickness and was presented to him. A few libraries are reported to its manuscripts like Khuda Bakhsh Library (Patna), Raza Library (Rampur) and Maulana Azad Library (Aligarh).

Dala'il Al-Baul ('Conditions of Urine', 942/1535) presents a system of aetiology by which conditions can be diagnosed by an analytical study of urine. Its manuscripts are in the libraries of Khuda Bakhsh Library (Patna), Asiatic Society of Bengal (Calcutta), State Manuscript Library (Madras), Salar Jang Museum (Hyderabad), Nizamiya College Library (Hyderabad), Raza Library (Rampur) and Maulana Azad Library (Aligarh).

Dala'il al-Nabz ('Condition of Pulse', 942/1535) discusses diagnosis by taking the pulse. A few manuscripts are available in the libraries of British Museum, Asiatic Society of Bengal (Calcutta), State Manuscript Library (Madras), Salar Jang Museum (Hydera- bad), Nizamiya Tibbiya College Library Hyderabad and Maulana Azad Library (Aligarh).

Sittah Zururiah (944/1537) deals with six principles of keeping health and compiled during the reign of emperor Humayun. The manuscripts are in the libraries of Asiatic Society of Bengal (Calcutta), Raza Library (Rampur), Salar Jang Museum Hyderabad and Maulana Azad Library (Aligarh).

Following the flurry of great advancement under the early Mughals, the learned community subsequently settled into compilation and commentary based on these pioneering efforts as the $16^{\text {th }}$ century progressed. Amraz-i-Chashm ( $16^{\text {th }}$ century), concerning ophthalmology, is the only surviving chapter of a medical encyclopaedia, one manuscript of which survives in the Bodleian Library (Oxford). Tibb-i-Yusufi is a collection of Hakim Yusufi's eight treatises discussed previously. Riyaz al-Adaviya (946/1539) was written during the reign of emperor Humayun, recording individual and compound medicines in alphabetical order. The manuscripts are in the libraries of Asiatic Society of Bengal (Calcutta), Salar Jang Museum (Hyderabad) and Maulana Azad Library (Aligarh).

Hakim Mir Abul Baqa was the talented student of Shaikhul Islam Shahid Ahmad Taftazani. Due to his outstanding knowledge, Emperor Babur retained him at court and sought his advice. When Humayun fell sick during his stay at Sambhal the specialist physician failed to treat him, thus Babur invited the dignitaries, nobles and religious scholars to voice their opinions. Mir Abul Baqa gave his opinion that from the very beginning it is customary practice that if anyone falls dangerously ill and every action failed, then charitable donations (sadaqa) should be made on behalf of the patient. Babur willingly accepted his advice, despite nobles austerely opposing and rejecting this spiritual medicine, but Babur with pleasure agreed to sacrifice his own life in favour of his son Humayun. Mir Abul Baqa also wrote a commentary on al-Kafiya ibn Hajib, a book on Arabic grammar. He died during the reign of Humayun in 948/1541.

Hakim Muhammad bin Ashraf al-Husaini was an excellent Hakim and expert in natural sciences and served both under Babur and Humayun. He wrote a book on the medical properties of precious stones and minerals.

Hakim Muhammad Beg served both under Babur and Humayun and left two books entitled Khwas al-Ashiya' (944/1537), and Dastur al-Fasd in which he explains the rules of Fasd (Venesection).

Hakim Khwaja Nizamuddin Ali Khalifa also came from Central Asia to India with Babur in 932/1526. He was one of the most trusted officials of Babur, who raised him to the position of prime minister. He was with Babur at the time of his death. He was an expert hakim and served under Humayun as a minister.

\subsection{Humayun (r. 1530-1556)}

Like Babur, Humayun also had literary taste but he was more interested in astronomy and mathematics (Akbarnama vol. 1,368), but he maintained a conventional sophisticated interest in Tibb and selected Hakim Yusuf ibn Muhammad as his personal secretary. He continued the services of his father's physicians in his court. Humayun died in 1556 in an accident at Delhi.

\subsection{Akbar (r. 1556-1605)}

Akbar ascended the throne at the very young age of 13 years. Like Babur and Humayun, Akbar was not highly qualified but he was not uneducated. Mualana Mir Abdul Latif Qazvini was one of his teachers who were teaching him Diwan-i-Hafiz (Badaoni, 1868). Due to Humayun's sudden death Akbar was unable to continue his education but gave high regard to scholars and learned men and was very much inclined towards education and learning, and he generously patronized physicians. He also had very high literary taste and gave much regard to atibba. Akbar founded a number of hospitals at Akbarabad, Fathpur Sikri, and Ahmadabad in which free food was served. Emperor Shahjahan appointed Hakim Mu- 
hammad Hashim as a tabib. However, there were numerous distinguished atibba, including ulama and surgeons, appointed and attached to his court, whose diverse origins can in many cases be ascertained from their epithets (e.g. 'Shirazi' refers to being from Shiraz, Iran, and 'Misri' refers to Egyptian provenance):

Bhimsen*

Bhiru Hindavi (Jarrah)

Biyar Chu (Kahhal and Jarrah)

Chandarsen Jarrah

Hakim Abdullah Lahiji

Hakim Abdur Rahim

Hakim Abul Fath Gilani

Hakim Ahmad Thattavi

Hakim Ainul Mulk Shirazi

Hakim Ali Gilani

Hakim Arastu

Hakim Bina Lahori

Hakim Fakhruddin

Hakim Fathullah Gilani

Hakim Hasan Gilani

Hakim Humam

Hakim Ishaq

Hakim Jibrail

Hakim Kamaluddin Husain Shirazi

Hakim Lutfullah

Hakim Mashhadi

Hakim Mir Tayyab Harvi

Hakim Muhamamd Amin Gilani

Hakim Muhamamd Husain Faghafur Lahijani

Hakim Muhammad Baqir Tabrizi

Hakim Muhammad Misri

Hakim Muhammad Nafis Gilani

Hakim Mulla Mir Sulaiman

Hakim Mullah Shihabuddin Gujarati

Hakim Muzaffar bin Muhammad Al-Husaini al-Shafai

Hakim Muzaffar Urdustani

Hakim Niamatullah

Hakim Nuruddin Qarari

Hakim Ruhullah

Hakim Saifuddin Shujai

Hakim Saiful Muluk Damawandi

Hakim Shah Fathullah Shirazi

Hakim Shaikh Hassan Panipati

Hakim Talib Ali

Hakim Zanbil Shirazi

Hakimul Mulk Shamsuddin Gilani

Mahadev*

Mulla Qutbuddin (Kahhal and Jarrah)

Narayan*

Shivaji*

*Ayurvedic

Hakimul Mulk Shamsuddin Gilani: a Persian, he joined the court of Akbar, and due to his outstanding knowledge and skill in the field of $t i b b$ received the title Hakimul Mulk (Wise of the nation). He studied and received his training under the guidance of Shaikh Muhammad Shahabadi. Apart from tibb he was expert in various disciplines, including nahw, fiqh and usul-i-figh. He was always surrounded by students and never ate food without them (Al-Hasani, vol. iv, pp. 140-41; Badauni, vol, iii, p.161). On the advice of Emperor Akbar, Hakim went to Makkah for hajj in 1580, and died in the same year. His son Hakim Abul Qasim Gilani became famous tabib and served the both courts of Emperor Jahangir (r. 1605-1627) and Shahjahan (r. 1628-1658) (Badauni, 1868; Rahman Ali).

Hakim Abul Fath Gilani: Masihuddin, Abul Fath and Son of Abdur Razzaq was an émigré of Lahijan, Gilan. A polymath with notable expertise in theology, medicine, philosophy, poetry and astronomy became the chief judge in the court of Muhammad Khan, the ruler of Gilan. After the Safvid conquest of Gilan, Abul Fath migrated to India along with his two younger brothers and joined the court of Akbar in 1575, where he was soon elevated to high position (mansab). He was very gentle, pious and generous, always offering food to students and the poor. Hakim died in 1588 and was buried at Hasan Abdal, while Emperor Akbar was travelling to Kashmir (Abul Fazl, 1882; Khan, 1895).

Hakim Shah Fathullah Shirazi: a Persian, he joined the court of Ali Adil Shah (1557-1580) of Bijapur as a prime minister. After the Shah's murder Hakim Fathullah joined Akbar's court on his invitation at Agra in 1583. Soon he was elevated to the position of sadr (Al-Hasni, 1999; Khan 1895; Azad, 2011). Hakim Fathullah was an intellectual and expert in astronomy, mathematics and theoretical and practical sciences. Due to his brilliance and expertise he was a favourite of the Emperor, and he drew the horoscope of Emperor Akbar with great acumen and enthusiasm (Khan, 1895).

He was a very religious and practical person, described by Akbar as his personal wakil (spiritual protector), philosopher, physician and astronomer. Hakim was so proficient that he made an automated windmill for grinding corn, a novelty mirror demonstrating strange images near at hand and far off, and a gun which could shoot twelve bullets at a time. He left many intellectual and philosophical writings. He received the title of Azdud Dawla (Arm of the State) and was sent to Khandesh to join Akbar's retinue in Kashmir in 1588. Hakim Fathullah became sick due to fever and died in 1588; he was temporarily buried in the shrine of Mir Saiyid Ali Hamadani and later reinterred in Koh-i-Sulaiman (Abul Fazl, 1882).

Hakim Humam: originally called Najibuddin Humayun, Akbar gave the forename Humayun Quli, which was later changed to Humam to differentiate him from the Emperor Humayun, the father of Akbar. Hakim Humam was the younger brother of Hakim Abul Fath who migrated from Gilan along with his brother. He was intelligent, sharp and eloquent in his speech. Akbar had great trust and promoted him, and used to send him on important diplomatic missions.

He was an outstanding tabib and Emperor Jahangir used to follow his advice regarding his personal health. Jahangir wrote that he fell sick due to excessive drinking of alcohol and was under the care of Hakim Ruhullah, Hakim Rukna and Hakim Sadra to no avail. Finally, he called Hakim Humam and whose expert opinion restored his health (Jahangir 2006). He died in 1595 at Lahore and was later buried at Hasan Abdal next to his brother Hakim Abul Fath (Badauni 1868).

Hakim Ali Gilani: a Persia, he joined the court of Akbar and soon entered in the circle of his trusted servants. Due to his outstanding intellectual ability and sharpness he became a respected figure in the eyes of scholars and courtiers (Badauni, 1868; Rahman Ali; Al-Hasani, 1999). Hakim Ali received a mansab (position) of 2000 under Akbar, increased under Jahangir to 3000 (Jahangir, 2006; Bhakkari, 1961). He was particularly expert in mathematics and hydraulics, and he invented a water tank (known as an Ali tank) with a total volume of $20 \times 20 \times 3$ yards. Within the tank there was a well-furnished room in which 10 to 12 people could sit, fitted with a bed, furniture, foodstuffs and books. The atmospheric pressure of the room was amazingly well balanced, such that water could not enter even when the door was open (Khan, 1895) Hakim Ali constructed another smaller tank (6x6 yards) in his own house at Agra, which even the Emperor Jahangir visited in 1609 (Jahangir, 2006).

Hakim Ali was a matchless and excellent tabib of his time who astonished people with his cures as well as his engineering feats (Jahangir 2006). Akbar once tested his skill by having him identify the urine samples from humans, animals and mixed, which he did successfully in all cases (Bhakkari, 1961). Due to his medical knowledge and skill Akbar had great trust in him (Abul Fazl, 1882)

A collection of his observations and prescriptions entitled $\mathrm{Mu}$ jarrbat-i-Ali Gilani (Prescriptions of Ali Gilani) are preserved in different libraries. A copy of this manuscript is available in the Arabic and Persian Research Institute (Tonk, Rajasthan) and the Asfiya Library (Hyderabad), India. His prescription of dev-dar oil 
(Indian pine) is a remarkable cure for joint, tendon and nerve pain, popular among modern Unani healers (Azmi. Hakim Ali died in 1609 during the reign of Emperor Jahangir.

\subsection{Jahangir (r. 1605-1627)}

Among the Mughal Emperors Jahangir was the most ardent promoter and patron of Unani medicine. He had good knowledge of $t i b b$ and personally conducted experiments to test various medical prescriptions and techniques. He observed changes in the climate and their impacts on one's physical health and temperament, and noted that each city has a particular climate and atmosphere that has biological impacts, including predisposing people to particular ailments, thus treatments should be tailored accordingly. He was also a practitioner of faith healing (Jahangir 2006). Some of the well-known physicians of Jahangir's court are explained below.

Hakim Sadra: a Persian, he joined the court of Akbar in 1602. His father's name was Hakim Fakhruddin Shirazi, whose pedigree links to the famous Arab physician Haris bin Kaldah, a contempo-

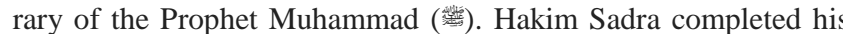
studies under the guidance of his father, who was a renowned physician of his time. In India, Hakim Sadra joined the circle of Hakim Ali Gilani (Khan, 1895; Lahori, 1867; Kambo, 1946). Emperor Jahangir raised his status (mansab) and assigned him title Masih-uz-zama in 1609. The Emperor painfully recorded that during his sickness Hakim Sadra refused to treat him (Jahangir 2006); this refusal may have been the fear of being reprimanded and professionally humiliated in the case of failure, as could often happen to physicians treating royalty and notables. However, during the reign of Shahjahan his status was further raised and he received a stipend of 20,000 and the region of Surat and the adjacent area. He left two books entitled Sharah Hidayat-ul-Hikmat (Way of Guided Wisdom) and Hifzul Sihat (Preservation of Health). Mulla Nizamuddin wrote a commentary on Hakim Sadra's work, dedicated to the Emperor Aurangzeb.

Hakim Momna Shirazi: a renowned hakim during the reign of Jahangir and Shahjahan, he initially joined the service of Mahabat Khan (d. 1634), a Mughal noble, and on the latter's recommendation he was incorporated in the galaxy of nobles of Jahangir in 1621 (Lahori, 1867; Kambo, 1946). He used to treat his patients by fasd (venesection) and twice applied this technique on Jahangir, receiving rewards of 10,000 and 1,000 respectively due to the success of the treatment (Jahangir 2006). He also treated the urinary problem of Aurangzeb (Kazim 1926).

Hakim Shaikh Hasan Hassu: son of Hakim Bina Lahori, he served Jahangir from childhood and was very loyal to him. He was very talented and excellent in archery and swordsmanship, due to his skill in which he accompanied Jahangir during hunting expeditions. Emperor Jahangir assigned him the title of Muqarrab Khan and a mansab of 3000 zat and sawar, later raised to 5000 zat and sawar (Jahangir, 2006). In 1613, he was appointed Governor of Bihar and was later transferred to Agra and assigned the position of Bakhshi (Pay Master) in 1620 (Khan, 1895). Due to his advanced age he retired from active service during Emperor Shahjahan and permanently settled in his hometown of Kerana in Saharanpur, Utter Pradesh. He planted an excellent mango garden there and constructed a water tank (220x200 square yards), which was visited by Jahangir (Jahangir, 2006).

He was a very talented surgeon and Jahangir admitted his wonderful skill in fasd (venesection) (Jahangir, 2006). Shaikh authored an excellent treatise on ophthalmology entitled Anisul Kahhal, translated into Urdu by Kalim Shahzad Ahmad Keranvi, and published in Delhi in 1899 (Azmi, 2014). He died at the age of ninety in 1646. His son Rizqullah was also an expert surgeon.

\subsection{Shahjahan (r. 1628-1658)}

Unlike Babur and Jahangir, Shahjahan was not a noted author in his own right, but he was a benevolent patron of scholars and learning, and a keen contributor to debates (Kambo 1946). He was interested in Unani medicine and built an advanced hospital next to the Jama mosque of Delhi, where he appointed experienced physicians (Khan, 1904). The Venetian traveller Manucci testified to the well organised and developed medical facilities he observed under the Mughals in India, particular as attributable to Shahjahan's reign (Manucci, 1907). Some of the well-known physicians of Shahjahan's court are explained below.

Tabibah Satti un-Nisan: the sister of Talib Amuli (d. 1627) and the wife of Nasirai Kashi, she came to India to meet her brother. She was the only recorded female physician under the Mughals and an expert in her discipline. Apart from tibb she was a brilliant poetess and an expert in housekeeping, domestic economy and childcare. Due to her polite behaviour she became very close to the Queen Mumtaz Mahal and was appointed as a tutor to Jahan Ara (Al-Hasani, 1999; Khan, 1895). She died at Lahore in 1646.

Hakim Nizamuddin Ahmad Gilani: a Persian born in Gilan in 1585 , he received his early education under the outstanding scholars of Persia. After completing his studies he migrated to India, and he joined the army of Shahjahan and served under the command of Mahabat Khan at Daulatabad. After completing this important assignment he joined the court of Qutb Shah at Golkunda. Hakim Nizamuddin left his Majmua Hakimul Mulk based on his medical expertise in the field of Tibb-i-Unani, a manuscript of which in the Asfiya Library (Hyderabad) runs to about 336 pages. Hakim Gilani extensively discussed on the topic of different medicines, its preparations and usage. The other books are Khulasat al-Tazkira fi Tibb al-Tajribah, Asrar al-Atibba (1635) and Istalahat-i-Atibba (1643); copies of both manuscripts are preserved in the Asfiya Library. Apart from tibb he was also expert in fine architecture. He died in 1649 (Azmi, 2014).

Hakim Daud Taqarrub Khan: he succeeded his father Enaytullah as the personal physician of Shah Abbas I (r. 1588-1629), but he fell from favour under the succeeding monarchs Shah Safi (r. 1629-1642) and Shah Abbas II (r. 1642-1667) due to his youth. After the Hajj pilgrimage, he went to India and joined the service of Emperor Shahjahan in 1643. Hakim Daud was rapidly promoted due to his expertise and successful treatment of Queen A'azzun Nisa Begum, known as Akbarabadi Mahal (Kambo, 1946; Mukharjee, 2001). Hakim Daud was a truly exceptional physician beloved to Shahjhan; during the war of succession, the victorious Aurangzeb allowed Hakim to continue serving Shahjahan at Agra, but he was later dismissed. He died in 1662 (Khan, 1895).

\subsection{Aurangzeb (r. 1658-1707)}

Emperor Aurangzeb was one of the most brilliant and highly qualified Mughal rulers. He was a great writer because of his elegant style of letter writing (insha') and a poet, who also took a great interest in $t i b b$, particularly in Tibb-i-Nabawi. On the desire of Emperor Aurangzeb, Hakim Muhammad Akbar Shah Arzani (d. 1722) translated into Persian Al-Manhaj al-Sawī wa al-Manhal alRawī fi al-Tibb al-Nabawī (The Straight Path and Quenching Spring: The Prophetic Medicine) by Jaluddin Suyuti (Elgood, 1979).

The Mughal court was a very popular and attractive focal point of Persian scientists, poets and hakims throughout the $16^{\text {th }}$ to $18^{\text {th }}$ centuries. One of the prominent Persian migrants was Nuruddin Muhammad Abdullah bin Hakim Ainul Mulk Shirazi, who wrote an outstanding work Alfaz-ul Adviyah (The Vocabulary of Drugs) (1628-29) for his patron Emperor Shahjahan. It is a Persian medical book on general therapeutics which was published in Calcutta in 1793, and translated into English by Gladwin. His other famous work Tibb-i-Dara Shikuhi (The Medicine of Dara Shikuh) is a colossal work considered a competitor in quantity not quality to the Ibn Sina's Canon or al-Jurjani’s Thesaurus (Elgood, 1979).

\section{Later Mughals}

The highpoint of Mughal culture during the $18^{\text {th }}$ century was contemporaneous with the height of Unani medicine in India, and Indian physicians continued to be of great renown and at the heart of court life; for instance, Hakim Mirza Muhammad Hashim 'Ala- 
vi Khan' Shirazi (1669-1748), the chief physician of Muhammad Shah, Emperor of Delhi was subsequently favoured by Nadir Shah (r. 1736-1747), who took him to Afghanistan. His grandfather had been a renowned tabib in Shiraz and Alavi Khan himself was one of the greatest physicians of his time (Elgood 1979; Rahman 2001; Azmi 2014). As mentioned previously, the main research activity upon which Unani medicine was based was already largely complete by the 1540s, and subsequent centuries refined and applied this system to exert its social utility. The proliferation of tibbi education was organized by reputed teachers and a greater emphasis was placed on practical skill during the $18^{\text {th }}$ century, with a comprehensive syllabus being developed at Dars-e-Nizami by Mullah Nizamuddin (d. 1747), which is still taught in traditional (religious) educational institutes in South Asia.

\section{Decline and renewal}

Increasing British control of India from the late $18^{\text {th }}$ century onwards led to a gradual dissemination of Western medicine around the garrison towns and British metropoles such as Calcutta, but Ayurvedic and Unani medical traditions remained vibrant until the late $19^{\text {th }}$ century, from which point the imperial culture of domination was generally disparaging to indigenous traditions. It must be noted that the internalised imperialism of Indians themselves was a central tool of cultural vandalism in effacing Indian heritage, while there was a concomitant interest in Indian sciences and knowledge among many Europeans. This was seen in the great popularity of Indian Hindu and Sufi philosophy in the West, and in some medical encounters of Europeans with traditional healing in India or in the West itself.

Hakim Muhammad Ajmal Khan (1868-1927), a hero of the Indian independence movement known as Masih-ul-Mulk (Healer of the Nation), toured London in 1911. As a tabib, Khan was invited to examine a patient of Dr. Staley Boyd, a senior surgeon in Charing Hospital, suffering from a gallbladder infection. Khan diagnosed an acute intestinal infection due to which the patient was suffering fever, pain and jaundice. The surgeon invited him next day in the operation theatre to watch his operation and clear for his disease. Surprisingly, the Hakim's prescription and prediction was correct, and the European wholeheartedly accepted his expertise and skill (Razzack, 1987; Nagrami, 2000).

On another tour in 1925, a disparaging French physician challenged Hakim Muhammad Ajmal Khan to diagnose a female patient suffering from a stomach-ache who was unable to raise her legs. Despite conducting x-rays, the French experts were unable to diagnose the problem. The Hakim asked the patient a few questions about her daily routine before sickness; she replied that she was fond of skating and horse riding. Not having the customary Unani prescription to hand, the Hakim nevertheless prescribed a pinch of medicinal powder he had to hand. He advised the patient to mix two grains of the powder in butter and eat it once a day for one week. The patient did so, whereupon she came walking to meet the Hakim. The French physician was astonished and asked the Hakim to explain. The aetiology was that riding and skating both caused the dislocation of her intestine from its original position, thus she developed a stomach ache and was unable to raise her legs; thus, the Hakim administered the medicine as an irritant to stimulate the intestine, which consequently returned to its original position. As part of the modern renewal of interest in traditional healing systems, the Unani heritage has much insight to offer modern health seekers (Razzack, 1987; Nagrami, 2000).

\section{Conclusion}

In the Islamic civilization on India, physicians and medical knowledge drawn from across the Subcontinent, Central Asia and the rest of the Islamic world were collated and a major research initiative was undertaken to empirically test, verify and develop medical treatment in a uniquely holistic and spiritual approach. Venerable but ineffective medicines were rejected, and uncommon methods and substances were shunned in favour of the most expedient treatments available to patients in need, as well as promoting preventive medicine and public health, alongside exploring alternative pharmaceutical methods to manufacture new medicines and cure patients. They did not confine their medical practice only to the knowledge they gained from Arabic and Persian medical books, rather they enhanced their practical knowledge in accordance with the Indian atmosphere and climatic conditions suitable to public demand and social requirements. In India, Unani physicians discovered a number of local herbs and studied their medicinal properties, and they included many Ayurvedic medicines in their daily practice. Many Indian medicines were prepared on the pattern of Ayurvedic style, and conversely a number of Unani medicines were incorporated into Ayurvedic medical practice (Rahman 2001).

Indo-Persian physicians in Muslim India developed a special aptitude in prescribing courses of treatment that calibrated pharmaceutical dosage and lifestyle regimen with the physical and metabolic properties of the patient relative to their occupation, socioeconomic status and geo-climatic locale in a remarkable and unique system of patient-centred, tailored care that is not to be found in modern systems. The art of writing prescriptions became an important discipline in its own right, based on seasonality as well as the condition and symptoms of the patient. They used new techniques in the preparations of Unani formulations, such as khamira, a semisolid Unani medicinal compound that was one of the rarest inventions of Indian physicians because of its unique flavour and medicinal significance.

By the apex of Mughal culture there was little differentiation between Ayurvedic and Unani medicine in India, and they were not viewed as fundamentally distinct by Indian scholars at the time. The efforts of Hakim Yusuf ibn Muhammad Harvi (Yusufi) in the court of Babur and Humayun, to develop a composite and integrated medical system through a synthesis of Arabian, Persian and Ayurvedic thought was an expression of this collaboration. Several others during the medieval period tried to bring the two systems together, including Hakim Nuruddin Muhammad Abdullah Shirazi (d. 1648), the personal physician of Shahjahan, and Muhammad Akbar Shah Arzani (d. 1722), and the court physician of Aurangazeb.

The Unani and Ayurvedic systems adopted drugs from each other. Muhammad Ali listed 210 plant drugs of Indian origin added by Unani physicians to their materia medica. The Ayurveda also incorporated in their pharmacopoeia several medicines from the Unani system. The result of this interaction, cooperation and collaboration synergised the traditional beliefs and practices of Ayurvedic physicians that are radically different from the classic texts. During the British colonial era the whole Tibb-i-Unani literature was transferred into Urdu at the beginning of the $19^{\text {th }}$ century, which completed the long-term underlying role of Muslim physicians in democratising medicine in South Asia, from a sacerdotal specialty to a near-universal system of knowledge integrated with a coherent worldview of human biology and illness within the surrounding spiritual and environmental ecosystem.

The total subversion of modern medicine as a sales wing of powerful corporate interests means that discerning people would do well to look into the Unani, Ayurvedic, Traditional Chinese and other traditional medical systems to benefit from the expertise of true giants of medical progress who were motivated by more elevated concerns than balance sheets, and to escape from the enslaving mantra of 'consult your doctor'. We conclude this paper by reiterating the hope of Hakim Muhammad Ajmal Khan for the preservation of traditional Indian sciences, lest "We will see our former greatness and glory in the hand of oblivion if we do not take thought to preserve it".

\section{Acknowledgement}

This research work is supported by the Project (RIGS16-1900354) supported by Research Management Centre, International Islamic University Malaysia. 


\section{References}

[1]. Abdullah. (1954). Tarikh-i-Daudi. S. A. Rashid (Ed.), Aligarh: Historical Research, A.M.U. press.

[2]. Ahmad, M.A. (1972). Political History and Institutions of the Early Turkish Empire of Delhi (1206-1290 AD). Delhi: Munshiram Manoharlal.

[3]. Al-Hasani, A.H. (1999). Al-I'lam bi Man fi al-Hind Min al-A 'lam known as Nuzhat al-Khawatir, Beirut: Dar Ibn Hazm, Vol. 2.

[4]. Agha, A. (1996). Tarikh-i-Tibb. Delhi: Mahbub Book Depot

[5]. Askari, S. H. (1957). 'Medicines and Hospitals in Muslim India', Patna: Journal of the Bihar Research Society, XLIII (1), 170.

[6]. Athar, M. (1976). Khilafat Abbasiya Aur Hindustan. Delhi: Nadwatul Musannifin.

[7]. Awfi, S.U.M. (1982). Lubab al-Albab. E.G. Browne (Ed.), Tehran: Fakhri Razi.

[8]. Azad, M. H. (2001). Darbar-i-Akbari. Lahore: Sang-e-Meel Publications.

[9]. Aziz, A. (1964). Studies in Islamic Culture in the Indian Environment. Oxford: Clarendon Press.

[10]. Azmi, A.A. (1992). Tarikh-i-Tib wa Attiba Daur-i-Mughliyah. Delhi: Maktabah Qasmi.

[11]. Azmi, A. A. (2014). Hindustan mein Tibb-i-yunani ka Aghaz wa Irtiqa. New Delhi: Aijaz Printing House.

[12]. Babur, Z. M. (2007). Waqa-i-Babur. Urdu trans. Yunus Jafrey, Karachi: Indus Publishers.

[13]. Badaoni, A.Q. (1868). Muntakhab al-Tawarikh. M. A. Ali (Ed.), Calcutta: Bibliotheca Indica.

[14]. Barani, Z. (2005). Tarikh-i-Firuz Shahi. S. A. Khan (Ed.), Aligarh: Aligarh Muslim University.

[15]. Bhakkari, S. F. (1961). Zakhirat al-Khawanin. S. M. Al-Haq (Ed.), Karachi: Pakistan Historical society.

[16]. Bhu'a, M. (1877). Ma"adan al-Shafa Sikandar Shahi. Lucknow: Nawal Kishore Press.

[17]. Browne, E.G. (1983). Arabian Medicine. Westport, Connecticut: Hyperion Press.

[18]. Dale, S.F. (2004). The Garden of the Eight Paradises: Babur and the Culture of Empire in Central Asia, Afghanistan and India (1483-1530). Leiden: Brill N.V.

[19]. Elgood, C. (1979). A Medical History of Persia. Amsterdam: APAPhilo Press.

[20]. Farishta, M. Q. H. S. (1884-5). Tarikh-i-Farishta. Lucknow: Nawal Kishore.

[21]. Fazl, A. (1882). Akbarnamah. M.A. Rahim (Ed.), Calcutta: Asiatic Society of Bengal

[22]. Hadi, N. (1995). Dictionary of Indo-Persian Literature. New Delhi: Abhinav Publications.

[23]. Hakim, A.K. C. (1960). Atibba-e-Ahde Mughliya. Karachi: Hamdard Academy.

[24]. Hameed, A.A. (1969). Physician-authors of Greco-Arab Medicine in India. New Delhi: Institute of History of Medicine and Medical Research.
[25]. Jaggi, O. P. (1981). History of Science and Technology in India: Medicine in Medieval India. Delhi: Atma Ram \& Sons.

[26]. Jahangir, N. M. (2006). Tuzuk-i-Jahangiri (Memoirs of Jahangir). A. Rogers. (Ed.) H. Beveridge, Trans). New Delhi: Low Price Publications.

[27]. Kambo, M. S. (1946). Aml-i-Salih, Vol. I, ed. Ghulam Yezdani. Calcutta: Bibliotheca Indica.

[28]. Kazim, M. (1868). Alamgir-Nama. M. K. Husain and A. Hai. (Ed.), Calcutta: Asiatic Society Bengal.

[29]. Khan, S. N. (1895). Ma'athir-ul-Umara. A.R. M. A. Ali. (Ed.), Calcutta: Asiatic Society.

[30]. Khan, S. A. (1904). Asar Oos-Sanadid. M. R. Rad. (Ed.), Cawnpore: The Nami Press.

[31]. Khusrau, A. (1933). Tughluq-Namah. H. Faridabadi. (Ed.), Aurangabad: Matba'ah Urdu.

[32]. Lahori, A. H. (1867). Badshahnama. K. Ahmad and A. Rahim. (Ed.), Calcutta: Royal Asiatic Society of Bengal.

[33]. Manucci, N. (1907). Storia Do Mogor or Mogul India (1653-1708). (W. Ervine, Trans.). London: John Murray, Albemarle Street.

[34]. Maulavi, R. A. (1961). Tazkira Ulama-i-Hind. Karachi: Pakistan Historical Society.

[35]. Minhaj, S. J. (1342/1954). Tabaqat-i-Nasiri. H. A. Al-Hai (Ed.), Kabul: Historical Society of Afghanistan.

[36]. Mukharjee, S. (2001). Royal Mughal Ladies and their Contributions, New Delhi: Gyan Publishing House.

[37]. Mushtaqi, R. (2002). Waqiat-i-Mushtaqi. I. H. Siddiqui (Ed.), Rampur: Raza Library.

[38]. Nagrami, M. H. (2000). Tarikh-i-Tibb. New Delhi: Taraqqi Urdu Bureau.

[39]. Nasr, S. H. (1984). Science and Civilization in Islam. Shah Alam: Dewan Pustaka Fajar.

[40]. Razzack, M. A. (1987). Hakim Ajmal Khan, the versatile genius. New Delhi: Central Council for Research in Unani Medicine, Ministry of Health \& Family Welfare, Govt. of India.

[41]. Rahman, S. Z. (2001). Aina-e Tarikh Tibb. Aligarh: Aligarh Muslim University Press.

[42]. Shibli, N. (1989). Maqalat-i-Shibli. Azamgarh: Matba’ Ma'arif.

[43]. Siraj Al-din, A.S. (1891). Tarikh-i-Firoz Shahi. M.V. Husain. (Ed.), Calcutta: Bibliotheca Indica press.

[44]. Siddiqi, M. Z. (1959). Studies in Arabic and Persian Medical Literature. Calcutta: Calcutta University Press.

[45]. Siddiqui, I. H. (1967). 'Masnad-i-Ali Mian Bhua: A Scholarly Statesman of Medieval India', Indo-Iranica. 20(3), 30-43.

[46]. Siddiqi, T. (1980). 'Unani Medicine in India during Delhi Sultanate', Indian Journal of History of Science. 15 (1): 18-24.

[47]. Verma, R. L. (1970). 'The growth of Greco-Arabian Medicine in Medieval India', Indian Journal of History of Science. 347-363.

[48]. Wasty, A. A. N. (1974). Tarikh-i-Rawabit Puzshaki Iran wa Pakistan. Rawalpindi: Sons Press. 